\title{
Determination of the Most Toxic Polychlorodibenzofurans in Fresh Milk from Southwest Iran
}

\author{
Azadeh Nakisa ${ }^{1}$, Zahra Nazari Khorasgani ${ }^{*}$, Mohsen Rezaei ${ }^{1,2}$, Nima Imani ${ }^{1}$, \\ Saeid Rezaee ${ }^{3}$ \\ ${ }^{1}$ Department of Toxicology \& Pharmacology, Pharmacy School, Ahvaz Jundishapur University of Medical \\ Sciences, Ahvaz, Iran \\ ${ }^{2}$ Department of Toxicology, Faculty of Medical Sciences, Tarbiat Modares University, Tehran, Iran \\ ${ }^{3}$ Departmentsof Pharmaceutics, Pharmacy School, Zanjan University of Medical Sciences, Zanjan, Iran \\ Email: znazarikh@yahoo.com
}

Received 4 May 2015; accepted 7 August 2015; published 11 August 2015

Copyright (C) 2015 by authors and Scientific Research Publishing Inc. This work is licensed under the Creative Commons Attribution International License (CC BY). http://creativecommons.org/licenses/by/4.0/ cc) (i)

\begin{abstract}
Background: Today's presence of polychlorinated dibenzofurans (PCDFs) in foodstuff, such as milk and milk products, is considered to be the major concern for human health. This study was aimed to determine the concentrations of the most toxic congeners of furans in pasteurized milk samples produced in southwest Iran. Material and method: 15 composite samples of pasteurized milk were collected from 3 major dairy factories in Khuzestan Province (southwest of Iran) in summer, autumn and winter from July 2011 to March 2012 . After precipitation of the proteins, fat phase was reduced and extracted with hexane and ether. After dehydration, furans existed in fat percolated with hexane through a column chromatography that contained respectively silica gel/silver nitrate, silica gel, silica gel/sulphuric acid and with percolating output through another column that contained activated charcoal and silica gel and washed the lower column with a mixture of dichloromethane-hexane and toluene, concentrated and dissolved in mobile phase and analyzed using HPLC: $150 \mathrm{~mm} \times 4.6 \mathrm{~mm}$ ID, $5 \mu \mathrm{m}$ cosmosil $5 \mathrm{NPE}$ column equipped with a UV detector at 254 and $235 \mathrm{~nm}$, mobile phase: methanol/water $(80: 20, \mathrm{v} / \mathrm{v})$ at flow rate of $1 \mathrm{ml} / \mathrm{min}$. Results: All samples were found to be contaminated with furans. The average concentration of 2,3,7,8 TCDF and $2,3,4,7,8 \mathrm{PCDF}$ were $1.91 \mathrm{pg} / \mathrm{g}$ and $1.77 \mathrm{pg} / \mathrm{g}$ in lipid content ranging from $2 \%$ to $3 \%$ respectively. The mean total content of furans in milk fat was 0.36 TEQ (Toxic Equivalency) pg/g which was below the recommended EU (European Union) threshold value $3 \mathrm{pg}$ (WHO-PCDFs-TEQ/g fat). Also, result showed that there were statistically significant differences between each factory during 3 seasons.
\end{abstract}

${ }^{*}$ Corresponding author.

How to cite this paper: Nakisa, A., Khorasgani, Z.N., Rezaei, M., Imani, N. and Rezaee, S. (2015) Determination of the Most Toxic Polychlorodibenzofurans in Fresh Milk from Southwest Iran. Food and Nutrition Sciences, 6, 955-963. 


\section{Keywords}

\section{Polychlorinated Dibenzofurans, 2,3,7,8 TCDF, 2,3,4,7,8 PCDF, Milk, HPLC}

\section{Introduction}

Polychlorodibenzofurans (furans) are a group of synthetic chemical pollutants that are produced during combustion of organic materials in the presence of chlorine such as combustion of paper, wood and forest fire or some of industrial processes [1]. These are one of the most toxic compounds known to human and were classified as carcinogenic by International Agency for Research on Cancer (IARC) in 1997 [2].

Among this group 2,3,7,8 TCDF and 2,3,4,7,8 PCDF have the most TEF (toxic equivalent factor) value [3]. Uncontrolled production of these materials leads to emission and persistence in environment, air, waters and soil because of their stability against biodegradation; they would remain in environment without any changes for many years [4]. Studies showed that the most important way for human exposure to furans ( $>90 \%)$ was food intake [5]. Due to the slow kinetics and high lipophilic properties of these materials, they can accumulate in fatty tissue [6]. Among the foods, milk and milk products are more important in healthy diet. Unfortunately many reports indicate the presence of furans in these products in many countries [7] [8].

For southwest of Iran, because of its geographical and industrial conditions, it has raised many concerns about the presence of pollutants in foodstuffs. This study was designed to somewhat address these concerns and analyze two furans in milk samples that produced in this area.

Various methods have been used for measuring the levels of furans, such as gas chromatography with the mass detector (GC-Ms), high resolution gas chromatography with high resolution mass spectroscopy (HRGCHRMS), high resolution gas chromatography with electron capture detector (HRGC-ECD), chemically activated luciferase gene expression (CALUX) bioassay, high performance liquid chromatography with the mass spectroscopy (HPLC-Ms) and HPLC with the UV detector [9]-[12]. Among these methods, HPLC with UV detector due to the high accuracy, device performance and economic condition was considered.

\section{Material and Method}

\subsection{Collection of Samples}

In this study $\mathrm{G}^{*}$ power software ( $\mathrm{G}^{*}$ Power is a tool to compute statistical power analyses for many different $\mathrm{t}$ tests) was used to determine sample sizes according to large effect size. So 45 composite pasteurized milk samples were taken that each comprising of 10 packs of pasteurized milk from 3 factories: Jamus Khoramshahr, Pegah Khuzestan, Torent Behbahan in 3 seasons (summer, autumn and winter) from July 2011 to March 2012. They were transferred to Toxicology lab, stored frozen $\left(-18^{\circ} \mathrm{C}\right)$ in glass container until analysis.

\subsection{Chemical, Reagents and Materials}

Furan standards (2,3,7,8 TCDF and 2,3,4,7,8 PCDF) purchased from Cambridge Isotope company, USA (1.2 ml of each with $50 \mathrm{ppm}$ concentration in N-Nonane). All solvents and material that used in this study such as methanol HPLC grade, acetonitrile, toluene, diethylether, hexane, sulfuric acid, potassium oxalate, silver nitrate, sodium chloride, silica gel 50G were purchased from Merck company in Germany.

\subsection{Stock and Working Standard Solution}

The Stock solution of furans contains 2,3,7,8 TCDF and 2,3,4,7,8 PCDF that prepared in methanol-water (80 20) with $1 \mathrm{ppm}$ concentration. Working standards of furans prepared by diluting stock standard at the concentrations of $0.75,1.25,2.5,5,10 \mathrm{ppb}$.

\subsection{Apparatus}

The Shimadzu 10 ADvp HPLC system (Japan) was equipped with a Shimadzu UV detector set at dual wavelengths; 254 and 235 nm, Shimadzu LC-10 ADvp pump, isocratic mode, Shimadzu DGU-14A degasser, Shi- 
madzu SCL-10 Avp system controller, LC solution software, the NPE column $(4.6 \times 150 \mathrm{~mm})$ packed with particles of Nitrophenylethyl group (5 micro meter diameter) which purchased from NACALAI, USA.

\subsection{Lipid Extraction}

The method of chemical analysis was based on extraction method that described by Kawashiro et al. in 2008 [13]. In order to extract lipids to $10 \mathrm{ml}$ of each samples, were added $10 \mathrm{ml}$ Ethanol, $0.4 \mathrm{ml}$ of potassium oxalate solution 25\%, $5 \mathrm{ml}$ diethyl ether, $6 \mathrm{ml}$ hexane respectively and shacked in decanter then organic phase containing furans separated by liquid-liquid extraction twice ( $6 \mathrm{ml}$ hexane were added for 3 times). The final extraction was washed with 5\%,10\%, 20\% sodium chloride respectively, dehydrated with sodium sulfate and dried.

\subsection{Cleanups}

Final extraction dissolved in $1 \mathrm{ml}$ hexane, percolated with $50 \mathrm{ml}$ hexane through filled two connected glass columns (10 cm length, $1 \mathrm{~cm}$ ID) respectively with $2 \mathrm{~g}$ anhydrous sodium sulfate, $1 \mathrm{~g}(10 \%)$ silver nitratesilica gel, $0.5 \mathrm{~g}$ silica gel, $0.5 \mathrm{~g}$ (44\%) sulfuric acid silica gel, $2 \mathrm{~g}$ anhydrous sodium sulfate (upper column) and $1 \mathrm{~g}$ anhydrous sodium sulfate, $0.5 \mathrm{~g}$ activated carbon silica gel, $1 \mathrm{~g}$ anhydrous sodium sulfate (down column). Furans remained in down column collected by firstly passing of $50 \mathrm{ml}$ of dichloromethane-hexane $25 \%$ and then $130 \mathrm{ml}$ toluene, dried and were eluted with $1 \mathrm{ml}$ of mobile phase [13] [14].

\section{Identification and Quantification of Furans}

20 micro liter of the above solution was injected to the HPLC. Mobile phase was methanol-water (80 - 20) and used at the flow rate of $1 \mathrm{ml} / \mathrm{min}$. Emission and extraction wavelengths were $254 \mathrm{~nm}$ (2,3,7,8 TCDF) and 235 $\mathrm{nm}(2,3,4,7,8 \mathrm{PCDF})$ respectively and column temperature was $30^{\circ} \mathrm{C}$. Retention times for 2,3,7,8 TCDF and 2,3,4,7,8 PCDF were $5.109 \pm 0.004 \mathrm{~min}$ and $5.629 \pm 0.004 \mathrm{~min}$ respectively in this condition (Figures 1-4).

Furans peaks in chromatograms were identified by comparing their retention time with those in standard chromatograms in the same conditions. Furans concentration were identified by quantitation of the peaks with using calibration curve (2,3,7,8 TCDF: 43501.20626X - 27180.72127, $\mathrm{R}^{2}=0.99948$ and 2,3,4,7,8 PCDF: $\left.32390.53544 \mathrm{X}-12080.08739, \mathrm{R}^{2}=0.99902\right) .0 .75,1.25,2.5,5,10 \mathrm{ppb}$ concentrations of furans were used for drawing calibration curve. All measurements were repeated 10 times for both of furans.

The limits of detection and quantitation for both of furans were respectively 0.1 and $0.3 \mathrm{ppb}$. Inter-day and intra-day's RSD \% were in range of 2.39 - 7.45 (2,3,7,8 TCDF), 3.34 - 6.91 (2,3,4,7,8 PCDF) and 3.60 - 7.52 (2,3,7,8 TCDF), 4.56 - 7.19 (2,3,4,7,8 PCDF) respectively (Table 1 \& Table 2).

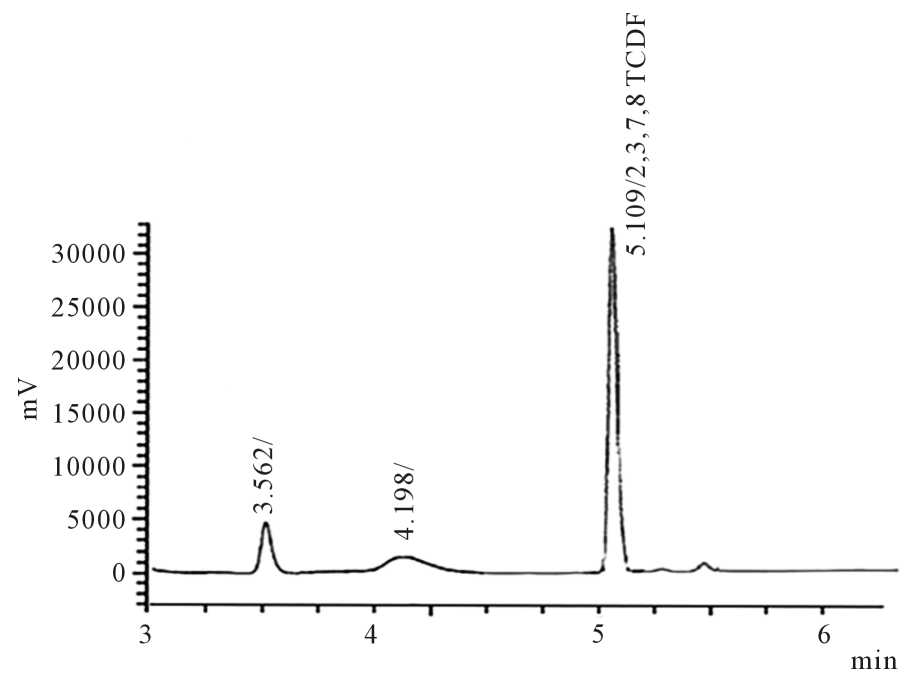

Figure 1. HPLC chromatogram of $10 \mathrm{ng} / \mathrm{ml}$ working standard solution of 2,3,7,8 TCDF and 2,3,4,7,8 PCDF, 254 nm wavelength, NPE column. 


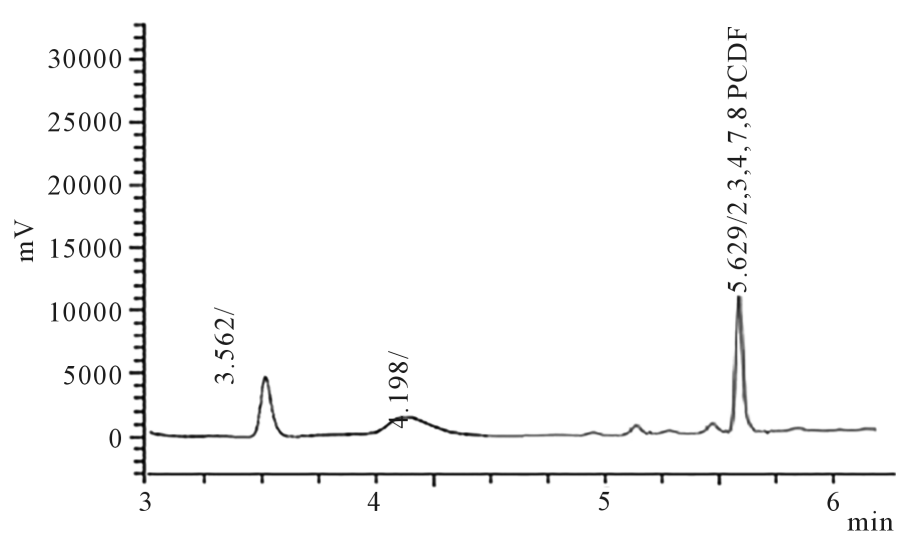

Figure 2. HPLC chromatogram of $2.5 \mathrm{ng} / \mathrm{ml}$ working standard solution of 2,3,7,8 TCDF and 2,3,4,7,8 PCDF, 235 nm wavelength, NPE column.

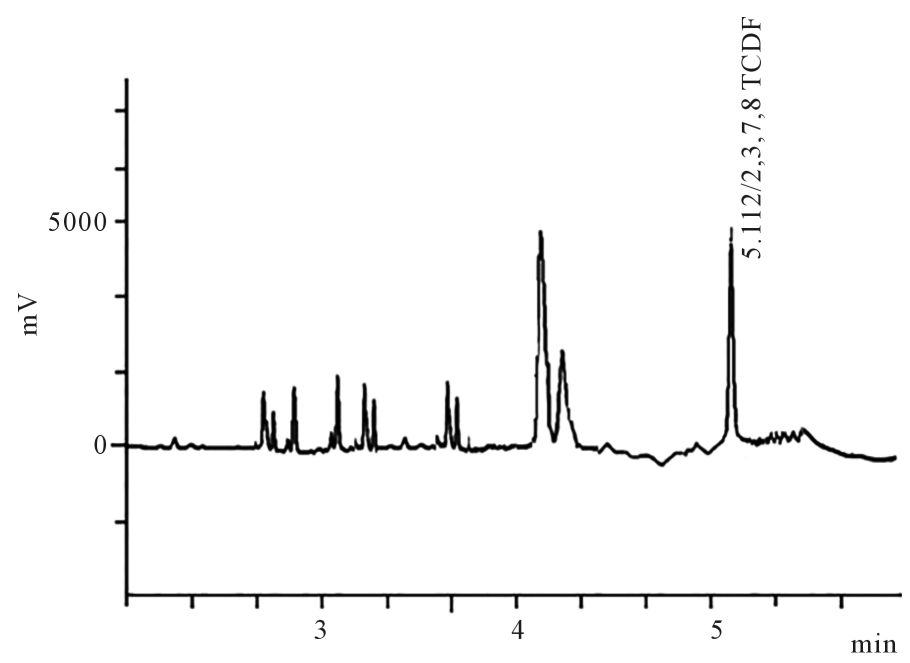

Figure 3. HPLC chromatogram of milk sample containing 2,3,7,8 TCDF, $254 \mathrm{~nm}$ wavelength, NPE column.

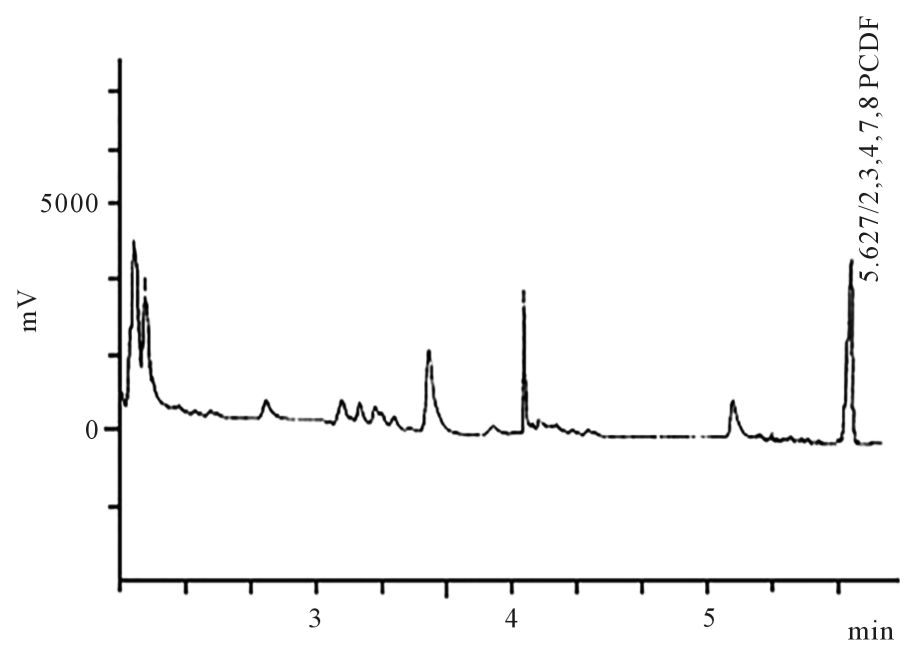

Figure 4. HPLC chromatogram of milk sample containing 2,3,4,7,8 PCDF, $235 \mathrm{~nm}$ wavelength, NPE column. 
These results show that the method has acceptable precision. The absolute recoveries of furans was done by adding furan standards at four concentrations to low contaminated samples and evaluated in range $82 \%$ - 86\% that results proving good accuracy (Table 3).

\section{Statistical Analysis}

We used SPSS (Statistical Package for the Social Sciences) software and general linear model (GLM) for analyzing data, because we considered two variable data: season and factory for comparing data.

\section{Results}

Results showed that 2,3,7,8 TCDF and 2,3,4,7,8 PCDF were present in all samples and concentration of PCDFs congeners which summarized in Table 4. The mean total content of PCDFs in milk fat was $0.36 \mathrm{pg} \mathrm{TEQ} / \mathrm{g}$ which was below the EU recommended threshold value (3 pg WHO-PCDFs-TEQ/g of milk fat). The average concentration of TCDF was $1.91 \mathrm{pg} / \mathrm{g}$ (range $0.37-3.40 \mathrm{pg} / \mathrm{g}$ fat) and the average concentration of 2,3,4,7,8 PCDF is $1.77 \mathrm{pg} / \mathrm{g}$ (range $0.35-3.03 \mathrm{pg} / \mathrm{g}$ fat) in lipid content ranging from $2 \%$ to $3 \%$. The highest concentration of 2,3,7,8 TCDF and 2,3,4,7,8 PCDF were 3.40 and $3.03 \mathrm{pg} / \mathrm{g}$ fat respectively that detected in sample of Jamus Khoramshahr factory in summer. The lowest concentration of 2,3,7,8 TCDF and 2,3,4,7,8 PCDF were 0.37 and $0.35 \mathrm{pg} / \mathrm{g}$ fat respectively that detected in Torent Behbahan factory in winter. In all factories the average

Table 1. Intra-day and inter-day RSD\% for2,3,7,8 TCDF (precision).

\begin{tabular}{|c|c|c|c|c|}
\hline $\begin{array}{c}\text { Concentration of } \\
2,3,7,8 \text { TCDF (ppb) }\end{array}$ & $\begin{array}{c}\text { Intra-day Mean + SD } \\
\left(\mathrm{mv}^{*} \mathrm{~S}\right)\end{array}$ & Precision (RSD \%) & $\begin{array}{c}\text { Inter-day Mean }+ \text { SD } \\
\left(\mathrm{mv}^{*} \mathrm{~S}\right)\end{array}$ & Precision (RSD \%) \\
\hline 0.75 & $1998.41 \pm 351.34$ & 7.52 & $2022.31 \pm 361.23$ & 7.45 \\
\hline 1.25 & $4223.42 \pm 432.48$ & 7.30 & $4315.92 \pm 441.21$ & 7.30 \\
\hline 2.5 & $8512.91 \pm 571.96$ & 6.33 & $8639.92 \pm 481.83$ & 4.79 \\
\hline 5 & $17,812.25 \pm 851.08$ & 4.02 & $18,902.23 \pm 764.32$ & 4.30 \\
\hline 10 & $37,510.12 \pm 976.51$ & 3.60 & $38,096 \pm 832.12$ & 2.39 \\
\hline
\end{tabular}

Table 2. Intra-day and inter-day RSD\% of 2,3,4,7,8 PCDF (precision).

\begin{tabular}{|c|c|c|c|c|}
\hline $\begin{array}{c}\text { Concentration of } \\
2,3,4,7,8 \text { PCDF (ppb) }\end{array}$ & $\begin{array}{l}\text { Intra-day Mean + SD } \\
\left(\mathrm{mv}^{*} \mathrm{~S}\right)\end{array}$ & Precision (RSD \%) & $\begin{array}{l}\text { Inter-day Mean }+ \text { SD } \\
\left(\mathrm{mv}^{*} \mathrm{~S}\right)\end{array}$ & Precision (RSD \%) \\
\hline 0.75 & $1713.41 \pm 381.21$ & 7.19 & $1823.24 \pm 378.12$ & 6.91 \\
\hline 1.25 & $3124.20 \pm 431.25$ & 7.12 & $3463.54 \pm 421.23$ & 6.76 \\
\hline 2.5 & $7189.91 \pm 581.34$ & 6.19 & $7235.81 \pm 512.23$ & 5.34 \\
\hline 5 & $14,287.32 \pm 867.21$ & 5.87 & $14,342.12 \pm 823.12$ & 5.45 \\
\hline 10 & $30,635.65 \pm 992.21$ & 4.56 & $31,759.24 \pm 864.29$ & 3.34 \\
\hline
\end{tabular}

Table 3. Recoveries of 2,3,7,8 TCDF and 2,3,4,7,8 PCDF from spiked samples of milk $(\mathrm{n}=10)$.

\begin{tabular}{|c|c|c|c|c|c|c|}
\hline \multirow{2}{*}{$\begin{array}{l}\text { Sample } \\
\text { Type }\end{array}$} & \multicolumn{2}{|c|}{ Equivalent concentration added (ppb) } & \multicolumn{2}{|c|}{ Measurable concentration (ppb) } & \multicolumn{2}{|c|}{ Mean Recovery (\%+SD) } \\
\hline & 2,3,7,8 TCDF & 2,3,4,7,8 PCDF & $2,3,7,8 \mathrm{TCDF}$ & $2,3,4,7,8 \mathrm{PCDF}$ & $2,3,7,8 \mathrm{TCDF}$ & 2,3,4,7,8 PCDF \\
\hline \multirow{4}{*}{ Milk } & 0.75 & 0.75 & 0.61 & 0.62 & $82 \pm 0.17$ & $83 \pm 0.17$ \\
\hline & 1.25 & 1.25 & 1.05 & 1.02 & $84 \pm 0.14$ & $82 \pm 0.15$ \\
\hline & 2.5 & 2.5 & 2.15 & 2.12 & $86 \pm 0.12$ & $85 \pm 0.14$ \\
\hline & 5 & 5 & 4.2 & 4.15 & $84 \pm 0.11$ & $83 \pm 0.11$ \\
\hline
\end{tabular}

$\mathrm{n}^{*}=$ number of repetition. 
Table 4. The concentration of 2,3,7,8 TCDF and 2,3,4,7,8 PCDF and TEQ concentration in investigated milk samples (ng/g fat).

\begin{tabular}{|c|c|c|c|c|c|c|c|c|c|}
\hline \multirow[b]{2}{*}{ Company } & \multirow[b]{2}{*}{ Season } & \multicolumn{2}{|c|}{ Mean } & \multicolumn{2}{|c|}{ Std. Deviation } & \multicolumn{2}{|c|}{ Maximum } & \multicolumn{2}{|c|}{ Minimum } \\
\hline & & $\begin{array}{l}2,3,7,8 \\
\text { TCDF }\end{array}$ & $\begin{array}{c}2,3,4,7,8 \\
\text { PCDF }\end{array}$ & $\begin{array}{l}2,3,7,8 \\
\text { TCDF }\end{array}$ & $\begin{array}{c}2,3,4,7,8 \\
\text { PCDF }\end{array}$ & $\begin{array}{l}2,3,7,8 \\
\text { TCDF }\end{array}$ & $\begin{array}{c}2,3,4,7,8 \\
\text { PCDF }\end{array}$ & $\begin{array}{l}2,3,7,8 \\
\text { TCDF }\end{array}$ & $\begin{array}{c}2,3,4,7,8 \\
\text { PCDF }\end{array}$ \\
\hline \multirow{4}{*}{$\begin{array}{l}\text { Pegah } \\
\text { Factory }\end{array}$} & Summer & 3.08 & 2.97 & 0.13 & 0.07 & 3.21 & 3.01 & 2.89 & 2.87 \\
\hline & Autumn & 1.73 & 1.76 & 0.16 & 0.27 & 1.94 & 2.01 & 1.29 & 1.50 \\
\hline & Winter & 0.43 & 0.52 & 0.16 & 0.02 & 0.53 & 0.55 & 0.39 & 0.49 \\
\hline & Total & 1.72 & 1.75 & 1.20 & 1.05 & 3.21 & 3.01 & 0.39 & 0.49 \\
\hline \multirow{4}{*}{$\begin{array}{l}\text { Jamus } \\
\text { Factory }\end{array}$} & Summer & 3.01 & 2.95 & 0.17 & 0.17 & 3.40 & 3.03 & 2.98 & 2.89 \\
\hline & Autumn & 2.38 & 1.96 & 0.57 & 0.07 & 2.96 & 2.01 & 1.87 & 1.86 \\
\hline & Winter & 0.83 & 0.83 & 0.04 & 0.03 & 0.90 & 0.88 & 0.79 & 0.81 \\
\hline & Total & 2.12 & 1.91 & 1.05 & 0.90 & 3.40 & 3.03 & 0.79 & 0.81 \\
\hline \multirow{4}{*}{$\begin{array}{l}\text { Torent } \\
\text { Factory }\end{array}$} & Summer & 3.03 & 2.75 & 1.09 & 0.25 & 3.20 & 2.96 & 1.03 & 2.39 \\
\hline & Autumn & 2.05 & 1.80 & 0.16 & 0.75 & 3.04 & 2.54 & 2.88 & 1.11 \\
\hline & Winter & 0.59 & 0.41 & 0.16 & 0.05 & 0.75 & 0.48 & 0.37 & 0.35 \\
\hline & Total & 1.88 & 1.65 & 1.20 & 1.08 & 3.20 & 2.96 & 0.37 & 0.35 \\
\hline \multirow{4}{*}{ Total } & Summer & 3.03 & 2.89 & 0.77 & 0.17 & 3.40 & 3.03 & 1.03 & 2.39 \\
\hline & Autumn & 2.05 & 1.84 & 0.64 & 0.43 & 3.04 & 2.54 & 1.29 & 1.11 \\
\hline & Winter & 0.61 & 0.58 & 0.19 & 0.19 & 0.90 & 0.88 & 0.37 & 0.35 \\
\hline & Total & 1.91 & 1.77 & 1.10 & 0.99 & 3.40 & 3.03 & 0.37 & 0.35 \\
\hline \multirow{2}{*}{\multicolumn{2}{|c|}{$\Sigma$ PCDFs-TEQ (pg/g fat) }} & \multicolumn{2}{|c|}{ Summer } & \multicolumn{2}{|c|}{ Autumn } & \multicolumn{2}{|c|}{ Winter } & \multicolumn{2}{|c|}{ Total } \\
\hline & & \multicolumn{2}{|c|}{0.59} & \multicolumn{2}{|c|}{0.38} & \multicolumn{2}{|c|}{0.11} & \multicolumn{2}{|c|}{0.36} \\
\hline
\end{tabular}

concentration of 2,3,7,8 TCDF and 2,3,4,7,8 PCDF were the highest in summer and the lowest in winter. There was significant decrease of the concentration of 2,3,7,8 TCDF and 2,3,4,7,8 PCDF from summer to winter but in the same seasons, there was not significant differences between concentration of PCDFs congeners in 3 factories (Figure 5 and Figure 6).

\section{Discussion}

Since milk and dairy products consume considerably worldwide as they have valuable properties for health, presence of toxic pollutants such as dioxin and furans raised many concerns and has been studies through many investigations.

In 2001 to 2003, G. Diletti et al. determined milk contamination by PCDD/Fs in total 274 milk sample (82 from cows, 77 from buffaloes, 85 from sheep, 16 from goats and 14 from sheep/goat) in Italy. The results showed that out of 274 samples, 99 (36\% of samples) exceeded the EU maximum tolerance level of $3 \mathrm{pg}$ WHO-TEQ/g fat [15]. Comparison these results with our study shows that in their study the average concentration of PCDFs in some of samples were above the tolerance level of $3 \mathrm{pg}$ WHO-TEQ/g fat but in our study the mean total content of PCDFs in all samples was below the recommended WHO threshold.

In 2001, P. Schmidt et al. determined levels of PCDFS in 30 cow's milk samples that collected from some of rural and industrial areas in Switzerland. The average concentration of PCDFs levels in milk from industrial area (0.63 +/- $0.26 \mathrm{ng}$ TEQ $/ \mathrm{kg}$ milk fat) was little but significantly higher than the average concentration of PCDD/Fs in milk from rural areas $(0.36+/-0.09 \mathrm{ng} \mathrm{TEQ} / \mathrm{kg}$ milk fat) [16]. The results of our study show that the average TEQ concentration of furans is similar to average concentration of PCDFs in rural investigated milk 


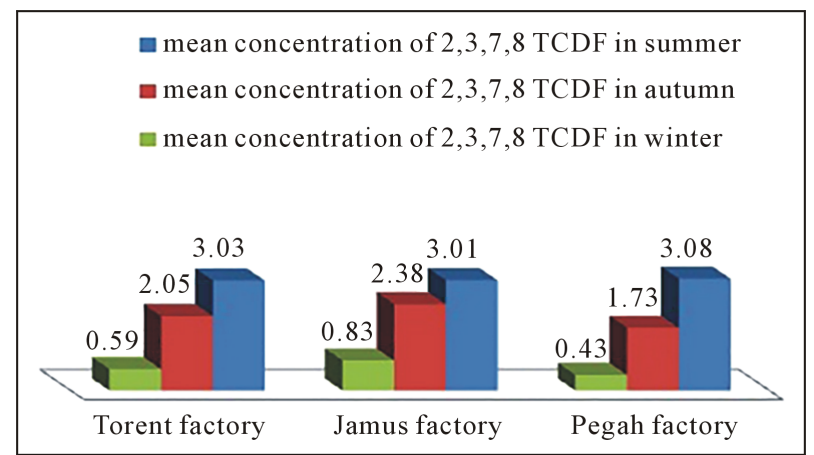

Figure 5. Concentrations of 2,3,7,8 TCDF in the milk samples of 3 factories in 3 seasons.

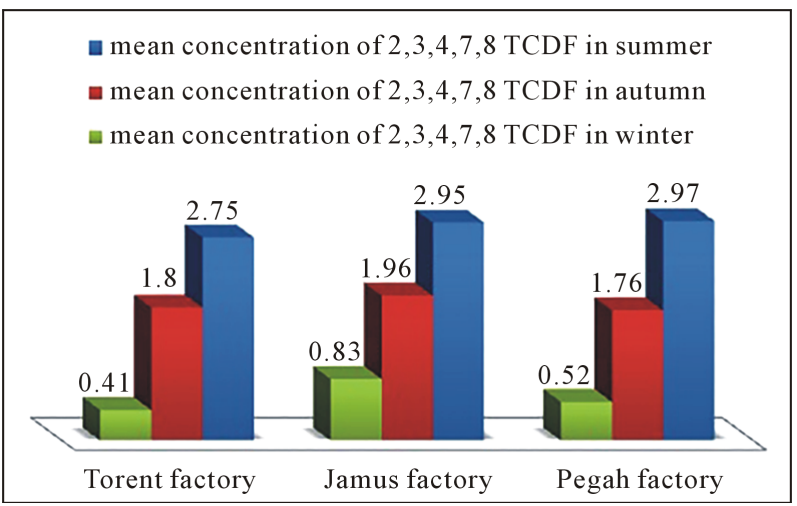

Figure 6. Concentrations of 2,3,4,7,8 PCDF in the milk samples of 3 factories in 3 seasons.

samples in this research but both of them are lower than the average level of PCDFs in milks from industrial areas in this research.

In 2003, J. F. Focant et al. studied occurrence of 7 congeners of Polychlorinated dibenzo-p-dioxins, 10 congeners of polychlorinated dibenzofurans and 4 non-orto (coplanar) polychlorinated biphenyls in 35 samples of commercial long-life pasteurized cow's milk in Wallonia (Belgium). The toxic equivalent value for PCDFs in all analyzed milks was $1.09 \pm 0.30 \mathrm{pg} \mathrm{TEQ} / \mathrm{g}$ fat (range 0.86 - 1.59), which was below the recommended EU threshold value of $3 \mathrm{pg}$ WHO-PCDD/Fs-TEQ/g of milk fat [17]. Comparison of data in this study with our research shows that the average concentration of PCDFs in our study ( $0.36 \mathrm{pg}$ TEQ/g fat) is lower than their result $(1.09 \pm 0.30 \mathrm{pg} \mathrm{TEQ} / \mathrm{g}$ fat) and both of them are below the recommended EU threshold.

In 2010, Mauro Esposito et al. studied distribution of PCDD/Fs and determined the concentrations of 17 PCDD/Fs and 12 dioxin-like PCBs in 460 samples of buffalo milk that collected in the Caserta province (Italy). The range of WHO-TEQ values for the PCDFs in milk was $0.17 \mathrm{pgTEQ} / \mathrm{g}$ fat to $87.0 \mathrm{pg}$ TEQ/g fat with a mean value $3.63 \mathrm{pg} \mathrm{TEQ} / \mathrm{g}$ fat and medium value $2.25 \mathrm{pg} \mathrm{TEQ} / \mathrm{g}$ fat [18]. According to their results the mean of total content of furans in this study ( $0.36 \mathrm{pg} \mathrm{TEQ} / \mathrm{g}$ fat) is more than the same result in our study ( $0.36 \mathrm{pg} \mathrm{TEQ} / \mathrm{g}$ fat) which is above the recommended WHO threshold value (3 pg TEQ PCDFs/g milk fat).

In 2012, M. Storelli et al. measured the concentrations of 7 polychlorinated dibenzo-p-dioxins (PCDDs), 10 polychlorinated dibenzofurans and 22 polychlorinated biphenyls (PCBs), including 12 dioxin like-PCBs (non and mono-ortho PCBs) in 80 sheep milk samples from farms that located in an industrialized area of Sardinia, Italy. PCDDs and PCDFs mean concentrations were 2.45 and $3.69 \mathrm{pg} / \mathrm{g}$ fat respectively. The results showed that contamination level of milk was below the limit values for human consumption established by European Commission (EC) legislation [19]. Comparison of data in this study with our results shows that the TEQ concentration of PCDFs in both studies is below recommended WHO threshold value (3 pg TEQ PCDFs/g milk fat).

In 2012, C. Scarano et al. determined the levels of PCDDs, PCDFs and Dioxin-Like PCBs in sheep milk that collected in Sardinia, Italy. The level of contamination with PCDDs, PCDFs and DL-PCBs was determined in 
45 row sheep bulk tank milk samples which collected from 15 extensively managed flocks in Sardinia. Milk samples collected near industrial sites showed widespread contamination by PCDDs and PCDFs. PCDFs concentrations was $3.11 \mathrm{pg} / \mathrm{g}$ fat and ranged between 0.20 and $7.47 \mathrm{pg} / \mathrm{g}$ fat. Among furans, the lower chlorinated penta PCDFs were in general more than the higher chlorinated PCDFs (hepta and octa PCDFs) [20]. According to these result the mean of total content of furans in this study (3.11 pg/g fat) is more than the same result in our study (0.36 pg TEQ/g fat) which is above the recommended WHO threshold value (3 pg TEQ PCDFs/g milk fat).

In 2011, J. Piskorska-Pliszczynska et al. studied the levels of PCDDs/PCDFs in row milk of cows and goats in Poland. The goal of their study was to assess the levels of 29 congeners of dioxins and furans in cow and goat's milk in Poland. High resolution gas chromatography coupled with high resolution mass spectrometry (HRGC- HRMS) was used to analyze more than 120 samples in the period of 2006 to 2011. In 94 samples of raw cow's milk an average concentration of PCDD/PCDFs was $0.84 \pm 0.60 \mathrm{pg}$ WHO-TEQ/g fat whereas the sum of 29 congeners was $1.35 \pm 0.89 \mathrm{pg}$ WHO-TEQ/g fat. The concentrations of dioxins and dl-PCBs were low (30\% of limits for whole milk) and the samples met the requirements of the national and European legislation [21]. Comparison of data in this study with our results shows that the TEQ concentration of PCDFs in both studies is below the recommended WHO threshold value (3 pg TEQ PCDFs/g milk fat).

\section{Conclusion}

Our results showed that although the TEQ concentration of PCDFs was below the recommended WHO threshold value (3 pg TEQ/g), 2,3,7,8 TCDF and 2,3,4,7,8 PCDF (furans with the most TEF) were detected in all samples. Because of lipophilic structure and their persistence, furans tended to bio-accumulate in human body by food consumption gradually and due to the toxic effects of them such as carcinogenicity, even low concentration of these pollutants can be risky. So the prevention of human exposure to these toxic substances should be considered by controlling industrial pollution, providing standards and regulations and developing food monitoring systems.

\section{Acknowledgements}

The research project is part of thesis by author Azadeh Nakisa with title of "Determination of two PCDFs in some of milks produced in Khuzestan province manufactories with HPLC method”.

\section{References}

[1] Schatowitz, B., Brandt, G., Gafner, F., Schlumpf, E., Bühler, R., Hasler, P. and Nussbaumer, T. (1994) Dioxin Emissions from Wood Combustion. Chemosphere, 29, 2005-2013. http://dx.doi.org/10.1016/0045-6535(94)90367-0

[2] McGregor, D.B., Partensky, C., Wilbourn, J. and Rice, J.M. (1998) An IARC Evaluation of Polychlorinated Dibenzop-dioxins and Polychlorinated Dibenzofurans as Risk Factors in Human Carcinogenesis. Environmental Health Perspectives, 106, 755-760.

[3] van Zorge, J.A., van Wijnen, J.H., Theelen, R., Olie, K. and van den Berg, M. (1989) Assessment of the Toxicity of Mixtures of Halogenated Dibenzo-p-dioxins and Dibenzofurans by Use of toxicity Equivalency Factors (TEF). Chemosphere, 19, 1881-1895. http://dx.doi.org/10.1016/0045-6535(89)90012-X

[4] La Rocca, C. and Mantovani, A. (2006) From Environment to Food: The Case of PCB. Annali-Istituto Superiore di Sanita, 42, 410-416.

[5] Llobet, J.M., Domingo, J.L., Bocio, A., Casas, C., Teixidó, A. and Müller, L. (2003) Human Exposure to Dioxins through the Diet in Catalonia, Spain: Carcinogenic and non-Carcinogenic Risk. Chemosphere, 50, 1193-1200. http://dx.doi.org/10.1016/S0045-6535(02)00630-6

[6] Heilier, J.-F., Nackers, F., Verougstraete, V., Tonglet, R., Lison, D. and Donnez, J. (2005) Increased Dioxin-Like Compounds in the Serum of Women with Peritoneal Endometriosis and Deep Endometriotic (Adenomyotic) Nodules. Fertility and Sterility, 84, 305-312. http://dx.doi.org/10.1016/j.fertnstert.2005.04.001

[7] Beck, H., Dross, A. and Mathar, W. (1992) PCDDs, PCDFs, and Related Contaminants in the German Food Supply. Chemosphere, 25, 1539-1550. http://dx.doi.org/10.1016/0045-6535(92)90182-Q

[8] Amlinger, D.I.F., Inc, W.C.E. and Pollak, D.M. (2004) Compost-Consulting \& Development.

[9] Bovee, T.F., Hoogenboom, L.A., Hamers, A.R., Traag, W.A., Zuidema, T., Aarts, J.M., Brouwer, A. and Kuiper, H.A. (1998) Validation and Use of the CALUX - Bioassay for the Determination of Dioxins and PCBs in Bovine Milk. 
Food Additives \& Contaminants, 15, 863-875. http://dx.doi.org/10.1080/02652039809374723

[10] Plomley, J.B., Lauševic, M. and March, R.E. (2000) Determination of Dioxins/Furans and PCBs by Quadrupole IonTrap Gas Chromatography-Mass Spectrometry. Mass Spectrometry Reviews, 19, 305-365. http://dx.doi.org/10.1002/1098-2787(2000)19:5<305::AID-MAS4>3.0.CO;2-T

[11] Bandh, C., Ishaq, R., Broman, D., Näf, C., Rönquist-Nii, Y. and Zebühr, Y. (1995) Separation for Subsequent Analysis of PCBs, PCDD/Fs, and PAHs According to Aromaticity and Planarity Using a Two-Dimensional HPLC System. Environmental Science \& Technology, 30, 214-219. http://dx.doi.org/10.1021/es950250t

[12] Martinez-Cored, M., Pujadas, E., Diaz-Ferrero, J., Coll, M., Martí, R., Broto-Puig, F., Comellas, L. and RodríguezLarena, M. (1999) Fractionation of Polychlorinated Dibenzo-p-dioxins, Polychlorinated Dibenzofurans and Planar Polychlorinated Biphenyls by High Performance Liquid Chromatography on a Pyrenyl-Silica Column. Fresenius Journal of Analytical Chemistry, 364, 576-583. http://dx.doi.org/10.1007/s002160051389

[13] Kawashiro, Y., Fukata, H., Omori-Inoue, M., Kubonoya, K., Jotaki, T., Takigami, H., Sakai, S. and Mori, C. (2008) Perinatal Exposure to Brominated Flame Retardants and Polychlorinated Biphenyls in Japan. Endocrine Journal, 55, 1071-1084. http://dx.doi.org/10.1507/endocrj.K08E-155

[14] Sun, S., Zhao, J., Leng, J., Wang, P., Wang, Y., Fukatsu, H., Liu, D., Liu, X. and Kayama, F. (2010) Levels of Dioxins and Polybrominated Diphenyl Ethers in Human Milk from Three Regions of Northern China and Potential Dietary Risk Factors. Chemosphere, 80, 1151-1159. http://dx.doi.org/10.1016/j.chemosphere.2010.06.021

[15] Diletti, G., Torreti, L., De Massis, M.R., Migliorati, G. and Scortichini, G. (2003) A Case of Milk Contamination by PCDD/Fs in Italy: Analytical Levels and Contamination Source Identification. Organohalogen compounds, 64, 1-4.

[16] Schmid, P., Gujer, E., Zennegg, M. and Studer, C. (2003) Temporal and Local Trends of PCDD/F Levels in Cow's Milk in Switzerland. Chemosphere, 53, 129-136. http://dx.doi.org/10.1016/S0045-6535(03)00439-9

[17] Focant, J.-F., Pirard, C., Massart, A.-C. and De Pauw, E. (2003) Survey of Commercial Pasteurised Cows’ Milk in Wallonia (Belgium) for the Occurrence of Polychlorinated Dibenzo-p-dioxins, Dibenzofurans and Coplanar Polychlorinated Biphenyls. Chemosphere, 52, 725-733. http://dx.doi.org/10.1016/S0045-6535(03)00127-9

[18] Esposito, M., Serpe, F.P., Neugebauer, F., Cavallo, S., Gallo, P., Colarusso, G., Baldi, L., Iovane, G. and Serpe, L. (2010) Contamination Levels and Congener Distribution of PCDDs, PCDFs and Dioxin-Like PCBs in Buffalo's Milk from Caserta Province (Italy). Chemosphere, 79, 341-348. http://dx.doi.org/10.1016/j.chemosphere.2010.01.025

[19] Storelli, M.M., Scarano, C., Spanu, C., De Santis, E.P.L., Busco, V., Storelli, A. and Marcotrigiano, G.O. (2012) Levels and Congener Profiles of Polychlorinated Dibenzo-p-dioxins (PCDDs), Polychlorinated Dibenzofurans (PCDFs) and Polychlorinated Biphenyls (PCBs) in Sheep Milk from an Industrialised Area of Sardinia, Italy. Food and chemical toxicology, 50, 1413-1417. http://dx.doi.org/10.1016/j.fct.2012.01.008

[20] Scarano, C., Storelli, M., Virdis, S., Mudadu, A., Spanu, C., De Santis, E. and Marcotrigiano, G. (2012) 2.8. (S2.30) Levels of PCDDs, PCDFs and Dioxin-Like PCBs in Sheep Milk Collected in Sardinia, Italy. Bulletin of the International Dairy Federation, 37-39.

[21] Piskorska-Pliszczyńska, J., Mikołajczyk, S., Maszewski, S., Warenik-Bany, M. and Góraj, Ł. (2012) Study of Dioxin Levels in Raw Milk of Cows and Goats in Poland. Proceedings of ECOpole, 6, 77-86. 